\title{
BIOLÓGIAI JELFELDOLGOZÁS ÚJABB MÓDSZEREI
}

\section{NEW METHODS IN BIOLOGICAL SIGNAL PROCESSING}

\author{
Márton László Ferenc ${ }^{1}$, Kocsis Lóránd ${ }^{1,2}$, Katona Norbert ${ }^{1}$, Szigeti Péter ${ }^{1}$ \\ ${ }^{1}$ Sapientia EMTE, Müszaki és Humántudományok Kar Marosvásárhely, Villamos- \\ mérnöki tanszék, Neural Systems Research Group (NSRG) kutatócsoport a Lambda \\ Communications SRL Marosvásárhely közremüködésével, martonlf@ms.sapientia.ro \\ ${ }^{2}$ Marosvásárhelyi Orvosi és Gyógyszerészeti Egyetem, Marosvásárhely
}

\begin{abstract}
We know that information is going in and that control signals come out. With this knowledge we try to work out basic functionalities. The brain generates electrical and magnetic fields that can be interpreted by our technology. Event related potentials can be recorded, the system learns them and can recall the linked control signal after a successful match. There are invasive and non-invasive methods. The project features non-invasive signal acquisition. The signal then is passed to the computer where the signal interpretation takes place. The implemented system uses the Savitzky-Golay filtering method the feature extraction is the main task, where a simple amplitude based method is used. And finally comes the classification of the selected patterns. We will show some example about Wavelet Transform (WT), Hilbert-Huang Transform (HHT), Dynamic Time Warping (DTW) and Detrained Fluctuation Analysis (DFA) as new methods in nonlinear non-stationary signal processing.
\end{abstract}

Keywords: local field potential, Hilbert-Huang transformation, dynamic time warping, detrended fluctuation analysis, fractal and chaotic dynamics

\section{Összefoglalás}

Az emberi test által generált biológiainak nevezett jelek nagyon nagy része nem sorolható a lineáris és stacionárius jelek osztályába. Ezért nagy körültekintéssel kell megválogassuk azon eljárásokat amelyek alkalmasok ezen jelek elemzésére Egy biológiai rendszer esetében általában nem ismert az információhordozó, sem az információ, sem a moduláció milyensége. Elemezni kell ezeket a megfelelő eljárásokkal. Az NSRG csoport által mért jeleket használtuk elsősorban az elemzések során. Nem a biológiai értelmezésen van itt a hangsúly, hanem az újabb lehetöségek ismertetésén amelyek sokat javíthatnak a biológiai rendszerek müködésének megértésében.

Kulcsszavak: Field potential, Hilbert-Huang transformation, Dynamic Time warping, Detrended Fluctuation Analysis

\section{Bevezető}

Egy egységnek tekinthető és kölcsönhatások és kölcsönös összefüggések által öszszekapcsolt objektumok halmaza egy rendszer. A rendszer meghatározása sok esetben önkényes valamely célszerü, müködésére vonatkozó meggondolást követ. Nagyon sokfajta, igencsak különbözően müködő, valamilyen funkciót betöltő részt tekinthetünk rendszernek [1],[2]. Beszélhetünk például vérkeringésirendszerről, nyirokrendszerből idegrendszerről, gazdasági rendszerről stb., amelyek nagyon komplex összetett rendszerek. Ehhez képest az érdemben általunk vizsgálni kívánt rendsze- 
rek esetében a rendszer határai eléggé jól láthatóak, müködésük nem mindég magától érthetö. A rendszereknek sokfajta osztályozási módszere létezik, ehhez a szakmát képviselő szakemberek hada szükséges. Ilyen értelemben vannak:

- koncentrált elemekböl felépített és osztott paraméterü rendszereket;

- determinisztikus valamint sztochasztikus müködési elveken alapuló rendszerek;

- folytonos és diszkrét rendszerek;

- stacionárius és nemstacionárius;

- lineáris és nemlineáris rendszerek és jelek stb.

A megkülönböztethető és egymástól egyértelmüen elválasztható bemeneti és kimeneti jelekkel rendelkező rendszereket irányított rendszereknek nevezzük. Természetesen mindkét jelfajtából több is lehetséges. A jelek fogalmához pedig elválaszthatatlanul hozzátartozik azok mérhetősége és információt hordozó képessége. A bemeneti jelből, rendszerből, kimeneti jelből álló séma az általánosan használt alapstruktúra. Általában egy rendszer jellemző három alkotóeleme (a bemenet; a rendszer és a kimenet) közötti általános érvényű összefüggések keresésére, értelmezésére irányulnak.

A hálózat fogalom használata csak arra utal, hogy többnyire rendszerkomponensekböl felépített rendszerek tulajdonságait keressük. Komplex rendszerek tulajdonsága, hogy a rendszer elvi múködési mikéntje nem ismert, és csak a mért és értelmezett bemenő és kimenő jelek alapos megismeréséből próbáljuk a rendszer működését megismerni (általában egy biológiai rendszer olyan információtovábbító rendszer, ahol nem ismert, hogy milyen információt milyen hordozójellel miként transzformál kimeneti jellé). Teljesen lineáris, akár stacionárius rendszerek szinte nem is léteznek.
A vizsgált biológiai rendszerek müködését általában csak elvi megközelítésben alig ismerjük. Az alkalmazott közelítések, modellek felvetik a numerikusan nyert megoldások érvényességének és alkalmazhatóságának kérdését. Ezeknek a kérdéseknek a vizsgálatát célozzák a dinamikai rendszerek elméletében bevezetett stabilitásfogalmak, mint a Ljapunov-stabilitás vagy a strukturális stabilitás. Valós lineáris rendszer nincs, de a rendszerparaméterek bizonyos tartományában tekinthetünk egy adott rendszert lineárisnak. Egy adott rendszert egy lineáris modellel megközelíteni azt jelenti, hogy egyszerüsíteni próbáljuk a rendszer müködésének dinamikájának megértését.

1. Jelek osztályozása:

1a. Determinisztikus

1a1. Periodikus

- Harmonikus

- Általános jelek

1a2. Nem periodikus

- Kváziperiodikus

- Tranziens jeltartomány (állandósult állapot elérése)

1b. Sztochasztikus

1b1. Stacionárius jelek

- Ergodikus jelek

- Nem ergodikus

1b2. Nem stacionárius

Stacionáriusnak és ergodikusnak azokat a folyamatokat nevezzük, amelyek statisztikus jellemzői az időben állandóak, és amelyek sok hasonló folyamat egyidejü vizsgálatával vagy egyetlen folyamat időbeni elemzésével egyaránt megkaphatók, vagyis az ún. időátlag és halmazátlag (sokaságátlag) azonos. Léteznek energiajelek (véges energiával rendelkeznek) és teljesítményjelek (véges teljesítménnyel rendelkeznek).

A leggyakrabban elektromos jeleket tudunk mérni, de fontos a kémiai jelek mérése is.

Ez a nem teljes körü osztályozás is mutatja, hogy sok nem konvencionális eljárás 
szükséges, hogy speciális hálózatokhoz kapcsolható jelek információtartalmát reálisan értelmezni tudjuk. Speciális jelértelmezés megfelelő mérési, elemzési eljárásokat igényel. Az ideális érzékelők (szenzorok) statikus karakterisztikája lineáris, a karakterisztika meredeksége a szenzor érzékenysége. Az élő szervezet müködése közben keletkező elektromos jelek megfelelő szenzorokkal, szürőkkel, erősítőrendszerekkel és adatrögzítő berendezésekkel viszonylag könnyen mérhetőek és rögzíthetőek, majd elemezhetőek. A biológiai eredetű elektromos jelek közül alapvető jelentőségü a központi idegrendszer diagnosztikai és kutatási célú vizsgálatában az elektroenkefalográfiás (EEG) görbe elemzése, valamint a szívmüködést jellemző elektrokardiogramok (EKG) vizsgálata. Spontán, illetve külső behatásra létrejövő változásaikból (ERP-Event Related Potential) igen sok következtetés vonható le a normális és patologikus müködésekre nézve. Így olyan jellemzők is vizsgálhatók, amelyek pusztán vizuális tapasztalatra építve nem észlelhetők, a szabad szemmel látható sajátosságok nem valósan mérhetőek. Az érzékelő legfontosabb jellemzője, hogy milyen kapcsolatot teremt a mérendő tulajdonság és a szolgáltatott adat között. Mivel általában a mérendő jel értékének időbeli alakulását kívánjuk meghatározni, a jel értékét a tulajdonság értéke mellett az idő függvényében is vizsgálni kell. A szenzorok elvárt tulajdonságai között említjük az érzékenységet, méréstartományt, feloldást, sávszélességet (dinamikus tulajdonság). A szenzoroknál előforduló fontosabb hibafajták között megemlítendő a hiszterézis jelenség (az érzékenységük a mért jellemző növekedése és csökkenése esetén nem azonos), tranziens hiba (az érzékelő nem képes követni a mért mennyiség értékének hirtelen megváltozását), zaj (a szenzor müködése során a jelben megjelenő véletlenszerü változást melyet nem a jel-tulajdonság változása, hanem a szenzor müködése vált ki), vala- mint az érzékelő véges feloldásából eredő eltérés. Az EEG, EKG görbe időben folyamatosan változó elektromos jel. Számítógépes feldolgozásának alapfeltétele, hogy az eredeti analóg jelet számsorozattá, vagyis diszkrét jellé, majd digitális jellé alakítsuk. Ezt alkalmas berendezéssel, az analógdigitális (A/D) konverterrel végezzük, amely egymástól azonos távolságra levő mintavételi időpontokban megméri az EEG jel amplitúdóját, és ezt digitális formában, vagyis számként továbbítja a számítógép felé. A mintavételező rendszer legfontosabb paramétere a mintavételezési periódus $\left(\mathrm{T}_{\mathrm{s}}\right.$ vagy $h$ ), valamint az ennek megfelelö mintavételezési frekvencia $\left(\mathrm{f}=1 / \mathrm{T}_{\mathrm{s}}=1 / \mathrm{h}\right)$. Ennek értéke jelfüggő, és a Shannon-Nyquistkritérium alapján határozzuk meg. Biológiai eredetü elektromos jelek közül alapvetö jelentőségü az agy (központi idegrendszer) elektromos tevékenységének időben történő követése Az elektromos aktivitást az agyban az agykéreg felszíne közelében elhelyezkedő neuroncsoportok szinkron müködése generálja (ionok irányított áramlásából származó elektromospotenciál-változás), az agykéregben mélyebben fekvő neuronoktól már gyenge a mérhető jel és az inkább háttérzajnak tekinthető. A biológiai jel egy összetett nem periodikus és általában nem stacionárius és nemlineáris jel. A jelfeldolgozás általában kétféle megszokott módszerrel történik napjainkban. Beszélhetünk idő- valamint frekvenciatartományban történő jelfeldolgozásról, de legújabb kutatások, elvi megközelítések alapján mind fontosabb eljárás a rendszerek idő-frekvencia tartományban történő elemzése.

A következőkben nemlineáris és nemstacionárius jelek vázlatos elemzésének újfajta bemutatására helyezem a hangsúlyt. A szakirodalomban közölt cikkek alapján a legfontosabb következtetés, hogy az, hogy sem a Fourier-transzformáció (FFT), sem a Short-Time-Fourier-transzformáció (STFT), nem képes valós mértékben visszaadni egy nemstacionárius jel tulajdonságait frek- 
venciatartományban, illetve időtartományban. Nyilvánvaló elönyeik mellett az ismert transzformációk (1. ábra) a következő hátrányokkal rendelkeznek.

FFT csupán periodikus jelekre ideális, feltételezi, hogy a frekvenciakomponensek végig jelen vannak a vizsgált jelben. Ezért nem lokalizálja (1. ábra) az összes előforduló frekvenciakomponenst időben. Az STFT egy időablakkal elemzi végig a jelet, annak reményében, hogy lokalizálni tudja az egyes, időben korlátozott előfordulású frekvenciákat. Az ablak mérete befolyásolja úgy a frekvencia, mind az időtartománybeli felbontást, így ha az ablak mérete nagy, a frekvenciatartomány felbontása nagy lesz, az időtartomány felbontásának rovására, míg a kis ablakméret gyenge frekvenciatartomány-beli felbontást és jó időlokalizációt jelent (határozatlansági reláció idő- és frekvenciatartományokra).

\section{2. Új módszerek nemlineáris nem- stacionárius jelek elemzésére}

\subsection{Idő-frekvencia tartománybeli elemzés}

Egy transzformáció sikere azon áll vagy bukik, hogy sikerül-e helyesen megválasztani a bázisfüggvényeket (anyafüggvényt, például hatodrendủ Morlet-függvény Wavelet-transzformáció esetében), amelyet aztán kihúzva (dilatáció) és összenyomva (kontrakció), illetve tologatva (transzláció) az elemzett jelből megkapjuk a jel adott bázisban való transzformációját (ez egy 3D kép idő-frekvencia-energia). Sok esetben hasznos a jel alaptulajdonságainak előzetes ismerete a bázisfüggvények helyes megválasztásához. Az 1. ábra mutatja a különböző transzformációk referenciajeleit.

A következő ábra egy egér MS (Medial septum) agyi részen mért jel Wavelet feldolgozása látható. A 2. ábrán az abszcissza az időkomponens míg az ordináta meg a frekvenciatartalmat reprezentálja. A színek meg az adott idő-frekvencia koordinátának az ábra jobb oldalán található skála szerinti energiaszintjét mutatják. A fekete körvonal a szignifikáns energiaszinteket jellemzi. Ennek a szignifikáns zónának a meghatározása arra vonatkozik, hogy az adott jel valóban tartalmazza azokat a komponenseket, vagy csak biológiai mért jelekre jellemző vörös háttérzaj (red noise) generálta információtartalom. Vagyis a háttérzaj képes generálni biológiai szerú jelkomponenseket. A bal és jobb alsó sarkok más színezése a jelek véges voltából származó pontatlanságok előfordulását szemlélteti, és ezeket a zónákat nem szabad figyelembe venni a jelek értelmezése során.

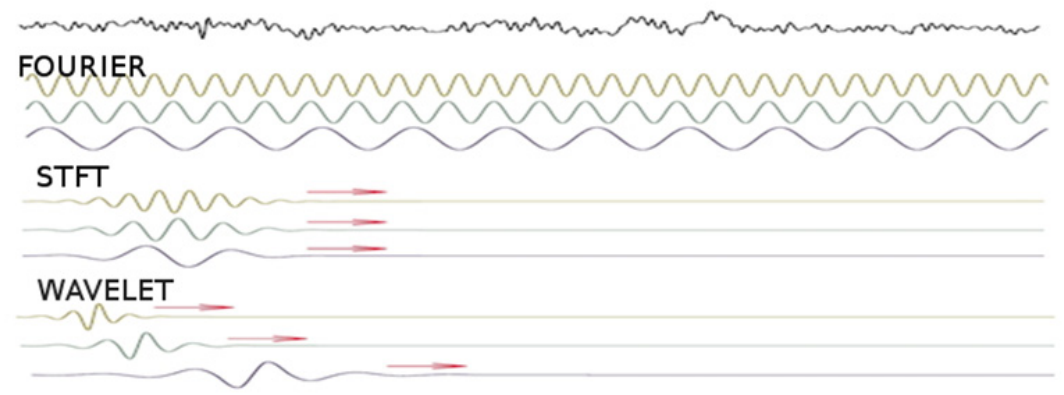

1. ábra. Biológiai jel Fourier-, SWFT(Gabor)- és Wavelet-transzformáció elvi alapjelei 


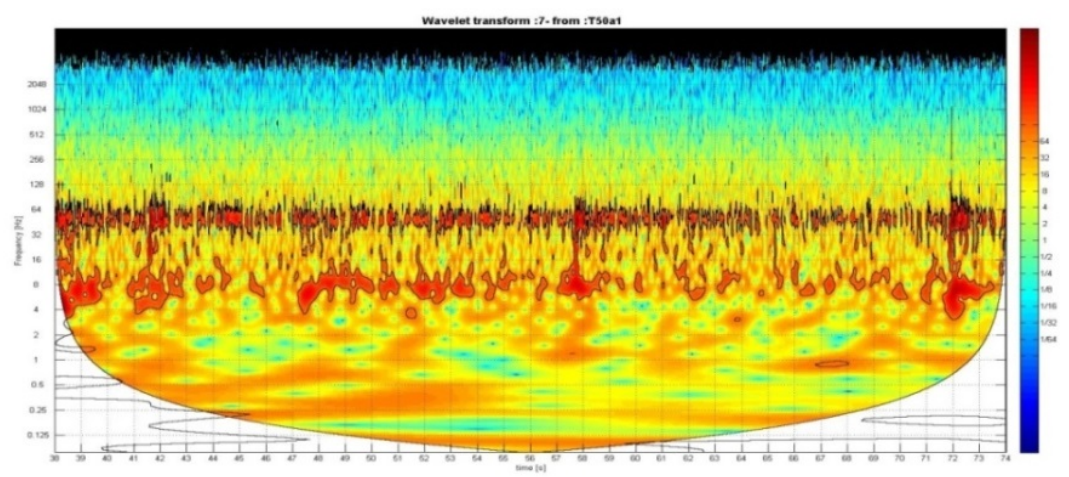

2. ábra. Egy jel wavelet-transzformációja. $64 \mathrm{~Hz}$ (Gamma), valamint $8 \mathrm{~Hz}$ (Theta) átlagú komponensek dominálják a jelet.

\subsubsection{Hilbert-Huang-transzformáció}

Az FFT módszer problémájára megoldást jelenthetnek a nemlineáris jelfeldolgozó transzformációk[10] (például a Wigner-Ville-eloszlás) vagy jeladaptív transzfor-mációk, mint a Hilbert-Huangtranszformáció. Ez utóbbi transzformáció két lépésből áll:

- empirikus moduszfelbontás (empirical mode decomposition - EMD) a jelet a nulla átmenetek és lokális szélsőértékpontok alapján ,általánosított” harmonikusokra bontja, ún. benső moduszfüggvényekre (IMF - intrinsic mode function);

- a kapott benső moduszfüggvények Hilbert-transzformációja segítségével kiszámolja azok pillanatnyi frekvenciáját és pillanatnyi amplitúdóját, amelyek nagyon fontosak a jelértelmezés szempontjából.

A felbontásból származó moduszfüggvények (IMF) olyan jelek, amelyekben egy adott időpillanatban egy adott frekvenciacsomag komponens van jelen. Egy IMF- et egy amplitúdó- és frekvenciamodulált jel szorzatának tekinti, és megpróbálja szétválasztani a két jelet úgy, hogy az IMF-re egy köbös spline-t illeszt, majd elosztja vele az IMF-et, és a müveletet addig ismétli, amíg az eredmény egy frekvenciamodulált (FM) jel lesz, amelynek a csúcsai a [-1 1] intervallumban vannak. Az eddigi tapasztalataim alapján egy átlag EEG-jel maximum 23 IMF komponensre bomlik. Ha az eredeti IMF-et elosztjuk a kapott FM-jellel, megkapjuk az amplitúdómodulált részt (AM). Az FM-rész és a kvadratúrája segítségével kiszámítható az IMF pillanatnyi frekvenciája. A Huang-transzformáció algoritmus formájában leírja a jelen végrehajtandó eljárásokat, ami elvezet minden IMF-jel való bontásához, majd a Hilbert-transzformáció elvezet a pillanatnyi frekvencia és pillanatnyi fázis fogalmához.

Az egyik első kérdés az, hogy mi jellemzi a fizikailag értelmezhető pillanatnyi frekvenciát. 

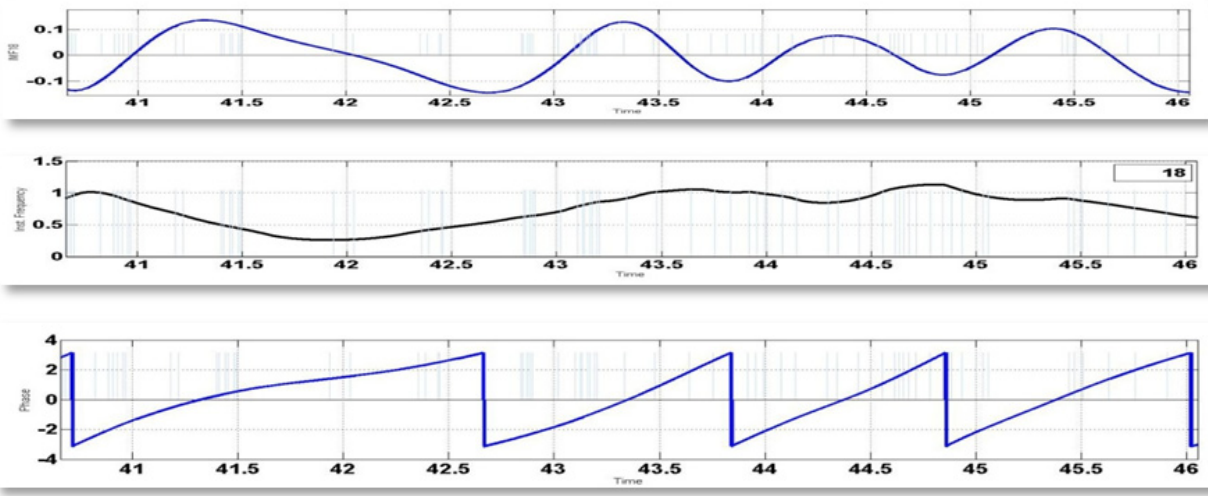

3. ábra. A HHT-transzformáció során egy IMF (felsö ábra) számitott pillanatnyi frekvencia (középsö ábra) és pillanatnyi fázis (alsó ábra). Minden idöpillanatra leolvasható a fázis és frekvencia értéke.

A természetes válasz az, hogy a pillanatnyi frekvencia legyen pozitív valós szám. Ezt követően felmerül, hogy olyan jel esetében, aminek nincs egyenáramú komponense, milyen jelbéli szerkezet az, ami negatív pillanatnyi frekvenciát ad. Ennek ismeretében ugyanis törekedni lehet az ilyen jelszerkezet elkerülésére a pozitív pillanatnyi frekvencia biztosítása érdekében. Abban az esetben, ha két egymást követő pozitív helyi maximum között található pozitív helyi minimum, avagy két negatív helyi minimum között található negatív helyi maximum, a pillanatnyi frekvencia negatív lesz. A természetes móduszfelbontás (EMD, Empirical Mode Decomposition) nevû algoritmust adták meg ezen összetevők elöállítására, amelyeket benső moduszfüggvényeknek (IMF, Intrinsic Mode Functions) neveztek el. A felbontást követően már a jelmodellezésből ismert módszerekkel, nevezetesen az egyes benső moduszfüggvények kanonikus reprezentációjának segítségével lehet meghatározni a pillanatnyi amplitúdót és a pillanatnyi frekvenciát. A szélsőértékek és a nulla átmenetek száma vagy azonos, vagy eltérésük egy egységnyi. A helyi maximumok és minimumok által kijelölt burkolók középértéke zérus. Az algoritmusban föszerepet játszik a leválasztási eljárás (sifting process), mert - szemléletesen szólva ezzel fejtünk le a jelről rendre egy-egy benső moduszfüggvényt (IMF). Mindeközben az eredeti jel (adatsor) helyi jellemzöivel kell számolni, így a benső moduszfüggvények a jelhez igazítottak lesznek, vagyis az eljárás ebben az értelemben adaptív. A leválasztási eljárás ezenfelül olyan, hogy az eredeti jel - egy maradékjeltől eltekintve - a benső moduszfüggvények öszszegzésével állítható elö. A benső moduszfüggvények számára nem tartalmaz elöírást, így azt többnyire tapasztalati úton kell meghatározni. Hilbert-transzformáltjából elő́llítjuk a

$Z(t)=\mathrm{x}(\mathrm{t})+\mathrm{j}$.

Hilbert $\{\mathrm{x}(\mathrm{t})\}=\mathrm{A}(\mathrm{t}) \cdot \mathrm{e}^{\mathrm{j} \Phi(\mathrm{t})}$

komplex analitikus jelet, akkor az ebböl származtatható

$\mathrm{x}(\mathrm{t})=\mathrm{A}(\mathrm{t}) \cdot \cos (\Phi(\mathrm{t}))$ 
kanonikus reprezentáció már egyértelmü, továbbá a pillanatnyi paraméterek is definiálhatók:

$$
\begin{aligned}
& \mathrm{A}(\mathrm{t})=\sqrt{x^{2}(t)+\operatorname{Hilbert}\{x(t)\}^{2}} \\
& \omega(t)=\frac{d \emptyset(t)}{d t}=\frac{d}{d t\left(\operatorname{atan}\left(\frac{\text { Hilbert }\{x(t)\}}{x(t)}\right)\right)}
\end{aligned}
$$

a pillanatnyi frekvencia.

\subsubsection{Wavelet-Transzformáció}

A Wavelet transzformáció [7] egy olyan eszköz, amely a jelet "wavelet"-eknek (hullámocskáknak) nevezett komplex bázis függvények összegére bontja fel. A waveletek olyan normalizált $\|\Psi\|=1$ függvények, melyeket egy "mother wavelet "-nek nevezett $\Psi(\mathrm{t})$ bázis függvényből eltolással és dilatációval és kontrakcióval állítunk elő. Egy idősor Folytonos Wavelet Transzformáció (Continuous Wavelet Transform -CWT) a jel wavelet függvénynyel vett belsőszorzatként definiálható, azaz

$$
\begin{gathered}
C W T\{f(a, b)\}=\int_{-\infty}^{+\infty} f(t) \Psi \cdot\left(\frac{t-b}{a}\right) d t, \\
a>0
\end{gathered}
$$

ahol „a” a nyújtásért (dilatáció) és zsugorításért (kontrakció) felelős skálaparaméter „,b” az eltolási (transzlációs) paraméter, míg „*” a komplex konjugált operátor.

Már említett „klasszikus” eszköz idősorok analízisére a STFT, gyakran nevezik ablakozott Fourier-transzformációnak is. Válasszuk wavelet-függvénynek a Morletkernelt ( $m=6$ egy módosított Gauss-görbét). ahol $a$ és $b$ skálázó faktorok. A Gauss-ablak fél szélessége a próbaperiódussal arányos, nem pedig állandó érték, mint a Fourieranalízisnél, így a frekvencia spektrumban a csúcsok fél szélessége nem egyforma, hanem a frekvenciával arányosan növekszik. $\mathrm{Az}$ ablakot $b$ értékkel toljuk el az adatsor elejétől a végéig, és minden eltolásra kiszámoljuk a frekvenciaspektrumot. A HHTmódszer, amely EMD-eljárásra épül, különbözik a jel Wavelet-módszerrel Morletfüggvénnyel történő konvolutiv szorzattól. A megválaszolandó kérdéstől függ a módszer megválasztása. Ha a jel spektrumának energiaváltozása érdekel időben, akkor a Wavelet-transzformációt választjuk mint elemzési módszert. A HHT nem igényel semmilyen bázisfüggvényt a konvolutiv elemzés elvégzésére. A jel komponenseinek meghatározása teljes mértékben adatfüggő (az IMF-re bontást nem befolyásolja egy bázisfüggvénnyel történő interferencia). Ha a jel teljesen sztochasztikus, akkor a HHT ajánlott eljárás, ha meg előzetes információnk van a jel időbeni viselkedéséről, akkor a Wavelet-transzformáció ajánlott.

Nagy különbség nincs a módszerek között, mert a jelgenerálás dinamikája ismeretlen. Az elemzési eljárások formai eljárások, a jelek formáját, dimenzióját és nem az alapvető, ezen jeleket generáló okokat elemzik. Ha a koherencia és korreláció tanulmányozása jelek viszonylatában fontos, hasznos módszerek a fáziskapcsolt jelek tanulmányozására (4. ábra).
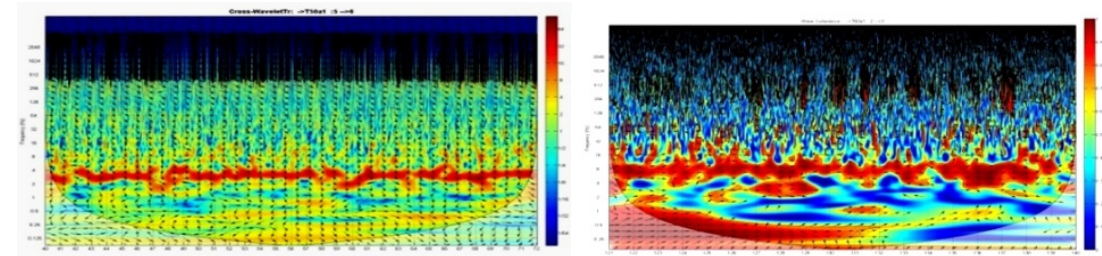

4. ábra. EEG-jelek Wavelet-koherenciája és korrelációja grafikus megjelenitése. Itt szerepel a szignifikáns zónák körberajzolása. A fázisviszony ábrázolását az ábrán megjelenitett apró nyilak iránya adja meg. 


\subsubsection{Cross Frequency Coupling}

A különböző biológiai jelek közötti kapcsolatának vizsgálata. Az alábbi ábrán kapcsolatok vizsgálatának egyfajta módsze- látható jelek közötti kapcsolatot tanulmáre [11] a jelek fázis-fázis, amplitúdó-fázis nyoztuk.
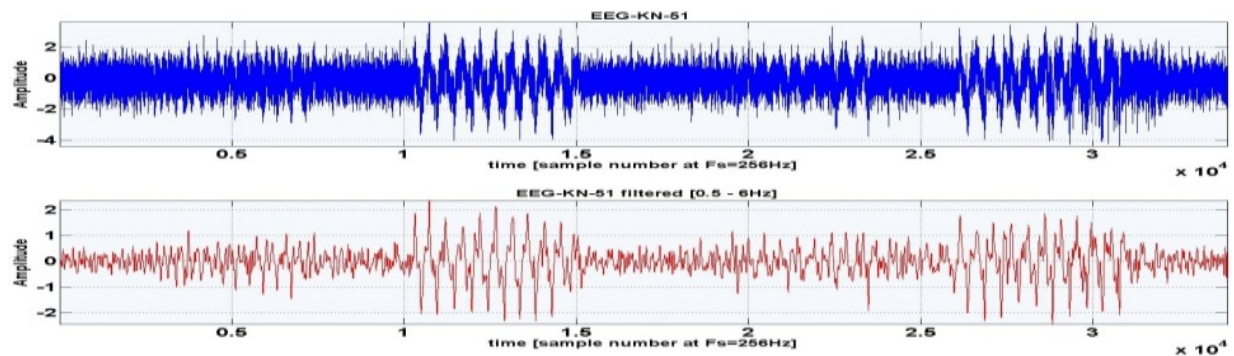

5. ábra. Általunk mért EEG-jelek

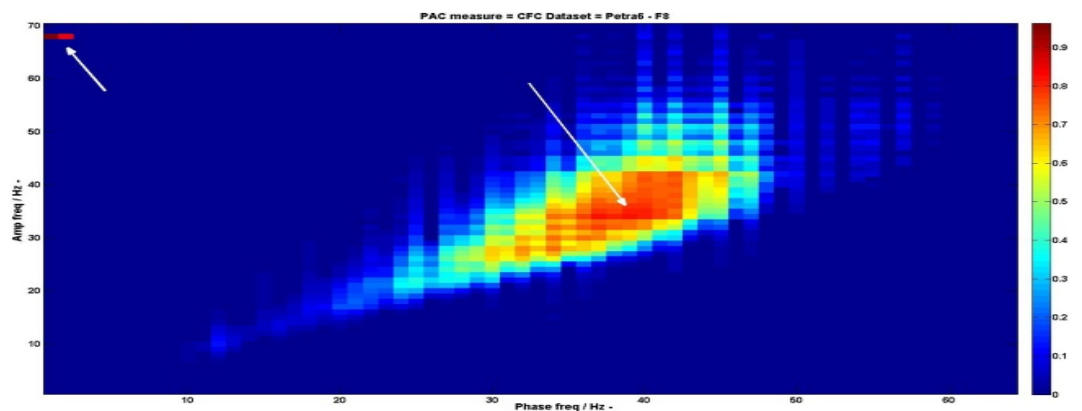

6. ábra. CFC két EEG-jel között (az egyik amplitudó-fázis kapcsolat a (30-40) Hz, a másik a (68-3) Hz-es frekvenciakomponensek között létezik.

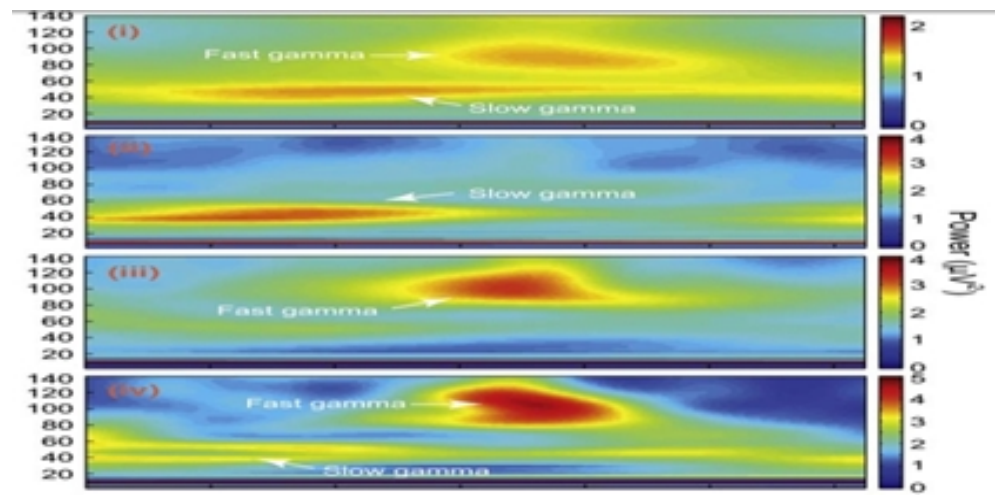

7. ábra. Különbözö biológiai frekvenciatartományok amplitudó-frekvencia kapcsolata biológiailag értelmezett gamma oszcillációk (lassú és gyors gamma komponensek) esetében 


\subsubsection{Dynamic Time Warping (DTW)}

A Dynamic Time Warping [6] algoritmus egy közismert algoritmus számos felhasználási körben. A 60-as években volt bevezetve, és a 70 es évekig alaposabban kielemezték, felhasználva a beszédfelismerő programokban. Mára kiterjedt a használata kézírás és aláírás felismerésére, mozdulatok felismerésére, adatbányászatra, és idősorok csoportosítására, biztonsági megfigyelö rendszerekre, zeneelemzésre.

A DTW egy sok helyen alkalmazható algoritmus, mert jeleket hasonlít össze. Minden olyan müvelet, amely valamilyen megadott jelet generál, felhasználhatja a DTW eredményeit.
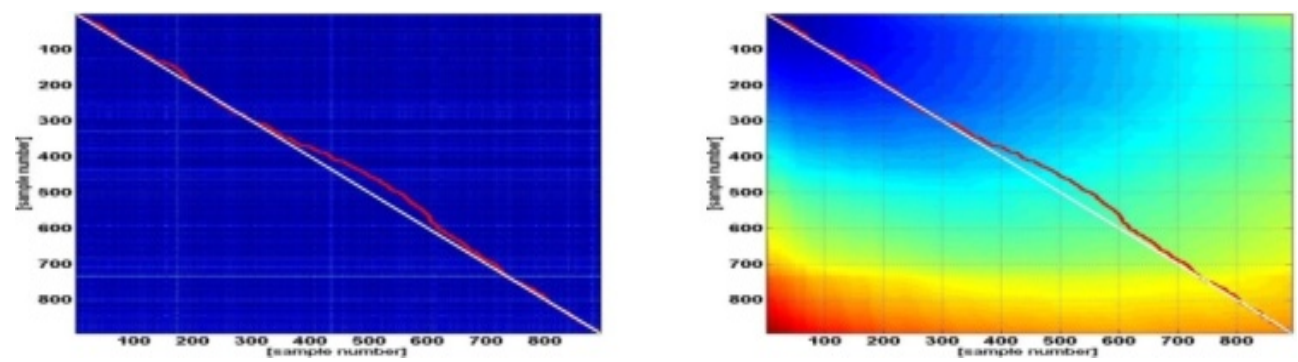

8. ábra. Két jel összehasonlitása DTW algoritmus alapján. A föátló egyenese teljes egyezést jelent. Az abszcissza az $x_{1}(t)$ és az ordináta $x_{2}(t)$ jeleket jeleníti meg. A föátlótól való eltérés a két jel különbözőségét mutatja.

\subsubsection{Detrended Fluctuation Analysis}

Biológiai jelek strukturális jellemvonásait [8][9] nagyon nehéz megfigyelni és értelmezni, annak kvantitatív értékeléséről nem is szólva. Egy $\mathrm{x}(\mathrm{t})$ biológiai jelet skálafüggetlen jelnek értékét. Kijelenthetjük, hogy a biológiai jelek nagy része fraktál ter- mészetü, tehát egy nemlineáris dinamikus rendszer müködésének terméke. Fraktált természetűnek nevezzük, ha igaz a $\mathrm{x}(\mathrm{ct})=\mathrm{c}^{\mathrm{H}} \mathrm{x}(\mathrm{t})$ összefüggés. A fraktálanalízis egyik célja, hogy megbecsülje a $\mathrm{H}$ exponens legmegfelelőbb értékét.

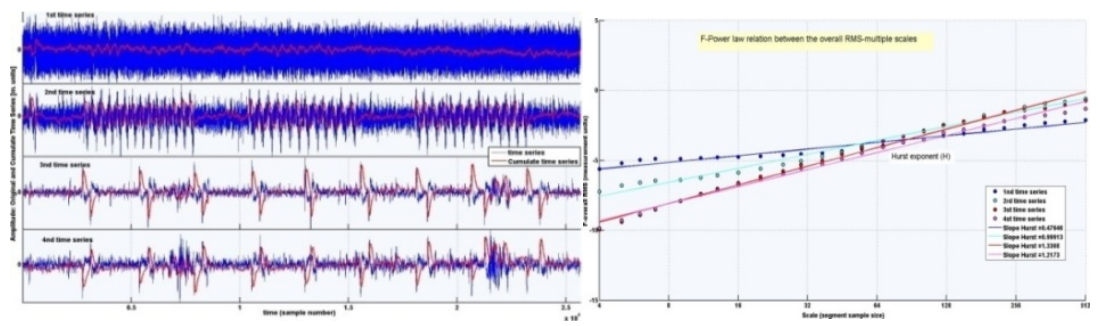

9. ábra. Biológiai jelek (kék jel), kumulatív összegezése (piros jel) és A Hurst-exponens (H) számitása az elöbbi 4 jel esetében 


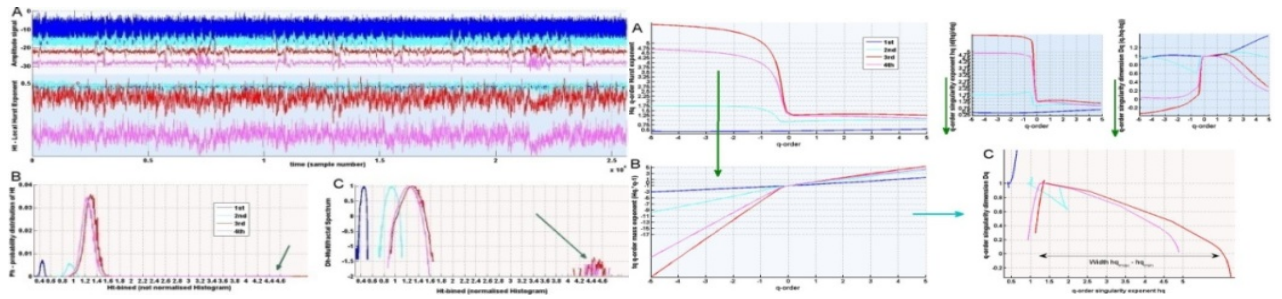

10. ábra. Multifraktál spektrum számitása a négy EEG-jel esetében. A jobb oldali ábra a Hurst exponens sürüségfüggvényei a 4 jelre, amelyek alapján jellemezni lehet a jelek fraktáltermészetét vagyis a nemlineáris nem-stacionárius rendszert, amelyek a jeleket generálhatják.

\subsubsection{Granger, fraktal, kaosz}

A káoszelmélet [5] olyan egyszerü nemlineáris dinamikai rendszerekkel foglalkozik, amelyek viselkedése az őket meghatározó determinisztikus törvényszerüségek ellenére sem jelezhető hosszú időre előre. Az ilyen rendszerek érzékenyek a kezdőfeltételekre. A sok összetevőből álló, bonyolult rendszerekről (például légkör, turbulens folyadékáramlás, lemeztektonika, gazdasági folyamatok stb.) régóta ismert, hogy bonyolult lehet a viselkedésük. A káoszelmélet nagy eredménye azonban annak kimutatása, hogy egyszerü, néhány állapotjelzővel leírható determinisztikus rendszerek is mutathatnak összetett, megjósolhatatlan viselkedést. Determinisztikus voltuk ellenére a kaotikus rendszerek állapotjelzői elsősorban statisztikus módszerekkel írhatóak le. A kaotikus viselkedést mutató rendszerek determinisztikusak, ellentétben a káosz szó hétköznapi jelentésével, ami totális rendetlenséget sugall. Valójában a káosz a viselkedés lokális instabilitásának és a globális keveredésnek az együttese. A viselkedés lokálisan instabil, ha egymáshoz közeli kezdőhelyzetből indítva a rendszert a különbségek gyorsan nőnek. Globális keveredésen azt értjük, hogy tipikus kezdőfeltételekkel indítva hosszú idő alatt az összes lehetséges állapothoz közel kerül a rendszer. Úgy szoktuk gondolni, hogy egy jó kísérletet jellemez az átlag és a variancia, és egy jó elméletet az jellemez, hogy képes megbecsülni egy kísérlet kimenetelét. Ez nem mindenképpen igaz. Nemlineáris rendszerek tulajdonságai a fraktál és káosz és ilyen rendszerek esetében nem könnyü a kimenet becslése. Fraktál természetü rendszerek kimenetele több skálára kiterjedhet, míg egy kaotikus rendszer nem ismétli meg a kimenő idősorát, még akkor sem, ha a kezdeti feltételek szinte azonosak. A fraktál és a káosz két megközelítési módja a komplex rendszerek elemzésének és megértésének. A fraktál egy olyan objektumrendszer, amelynek mind több mind kisebb része van. Egy ilyen rendszer önazonos, ha a kisebb része kicsinyített mása a nagyobb részének. A legtöbb természetben található fraktálrendszer esetében a kisebb rész kicsinyített mása a nagyobb résznek. A kicsinyítési arány lehet pontos vagy megközelítő. Egy fa struktúrája ez az utóbbi. Egy fraktál lehet egy időfüggő eseménysor. Ebben az esetben létezhetnek mind nagyobb számban mind kisebb amplitúdójú fluktuációk. Fraktál lehet egy kísérlet adatsora. Ebben létezhetnek nagyon nagy és nagyon kicsi értékek. Ez azt jelenti, hogy egy megfelelö matematikai modell nem képes becsülni egy kimenő idősor értékeit. Nemlineáris rendszerek esetében két fontos tanulság van:

1. hogyan használjuk a statisztikát a kísérleti adatok elemzésére;

2. hogyan döntjük el egy matematikai modell helyes voltát.

Klasszikusan a káoszelmélet a determinisztikus rendszereket tanulmányozza, de 
létezik a fizikának egy kvantumkáoszelméletnek nevezett területe, amely a kvantummechanika törvényeit követő nem determinisztikus rendszerekkel foglalkozik. A Granger eljárás képes ok-okozati kapcsolatot elemezni biológiai idősorok elemzésében.

Egy másik leírása egy nemlineáris rendszernek a káosz. Úgy gondolták kezdetben, hogy egy nagyon bonyolult kimenetet csak egy nagyon bonyolult rendszer képes generálni. Az ilyen rendszereknek az a meglepő tulajdonsága, hogy használhatjuk (teljes mértékben megbecsülhetjük a rendszer müködését) egy rövid időintervallumra, de nem használhatjuk a becslést hosszú időintervallumokra.

A kaotikus rendszerek legfontosabb jellemzői a következők: szabálytalan dinamika, kis kezdeti eltérések a kezdeti állapotokban, nagyon különböző választ generálhat, és bonyolult, de jól meghatározott fázistérbeli geometriai modell (határciklus).

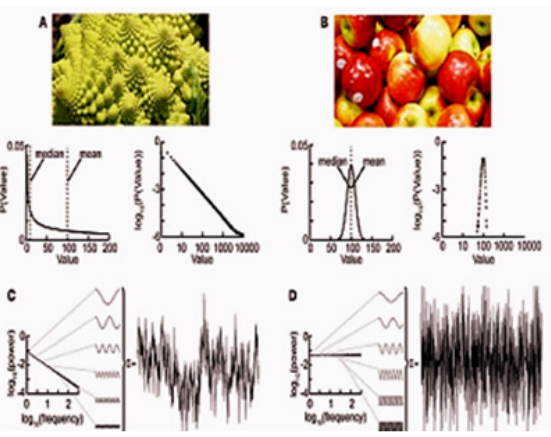

11. ábra. Jobb oldali rész: fraktál természet önazonos és arányosan azonos jelek esetében statikus és dinamikus rendszerek esetében. Bal oldali rész: (A) skálamentes természetes struktúra (zöldség). Ebben az alkotórészek hatványtörvény eloszlást mutatnak, amely log-log skálán egy egyenest ad, (B) almák halmaza, amely normál eloszlású halmaz. (C) fraktál természetü jel (a frekvenciakomponensek amplitúdója forditottan arányos a frekvenciájával. (D) fehér zaj, egyenletes eloszlású frekvenciakomponensek) [12 alapján].

Jelenleg a leggyakoribb statisztikai eljárás az, hogy többször megismételve egy kísérletet kiszámítjuk a kapott értékek átlagát. Annyira megszokott, hogy szinte automatikusan végrehajtjuk. Általában úgy gondolunk adatainkra, hogy nagyon sok érték van az átlag körül, de jóval kevesebb érték van, amely kisebb vagy nagyobb az átlagnál. A valószínűségi sűrüség függvény, a $\operatorname{PDF}(\mathrm{x})$ megadja annak valószínüségét, hogy egy mért érték $x$ és $x+d x$ között van. Ezeket a jellemzőket számszerüsíteni is lehet, a bonyolult viselkedést a topologikus entrópia, a kezdeti eltérések gyors növekedését a Ljapunov-exponens, a szokatlan geometriát a fraktáldimenzió jellemzi. A topologikus entrópia (h) a rendszerben levő periodikus pályák számáról ad információt. Kaotikus rendszerekben minél hosszabb periodikus pályákat keresünk, annál többet fogunk találni. A periodikus pályák száma exponenciálisan nő a periódus hosszának növekedésével: Kaotikus rendszerekben két tetszőlegesen választott, egymáshoz közeli kezdőhelyzetből indított pálya tipikusan exponenciálisan távolodik egymástól a fázistérben. A távolodás mértékét a lokális Ljapunov-exponens jellemzi: kaotikus disszipatív rendszerekben a mozgás hosszú idő után egy bonyolult geometriájú alakzaton, különös attraktoron zajlik. Kaotikus konzervatív rendszerekben a fázistérben 
kaotikus tengert találunk, és abban egymás körül hierarchikus rendszerbe foglalt reguláris szigetek vannak. A kaotikus viselkedés tehát bonyolult geometriai struktúrák felbukkanásával jár. Ezt a bonyolult struktúrát a fraktáldimenzióval lehet jellemezni. Az, hogy a minták átlaga növekszik vagy csökken, a kisebb elemek a nagyokhoz mért relatív számától függ. Ha mind több kicsi elemet veszünk figyelembe, amint a minták száma növekszik, akkor az átlag csökkeni fog és növekedni fog, ha mind több nagy elemet veszünk figyelembe. Ilyen eset jellemzésére a fraktáldimenzió paramétert használjuk. A d fraktáldimenzió az új elemek száma $(\mathrm{N})$, amelyeket akkor vesz-nk figyelembe, amikor a rendszert egy finomabb felbontásban (rezolúció) r vizsgáljuk.

$$
\mathrm{d}=\log (\mathrm{N}) / \log (1 / \mathrm{r}) \text {. }
$$

A $d$ a mértéke a kicsi elem aránya a nagyokhoz képest. Ez összefüggésben van a teljesítmény-eloszlás PDF függvényének meredekségével. Valójában nagyon sok természetbéli rendszer nem normál eloszlású. Általában ezek esetében a rendszer mind több nagyobb, valamint kisebb elemből épül fel. Nincsen csak egy érték, mint az átlag, amely megfelelően jellemzi (leírja) azt a rendszert (fa, hegyek, szigetek, partszakaszok fraktál természetüek).

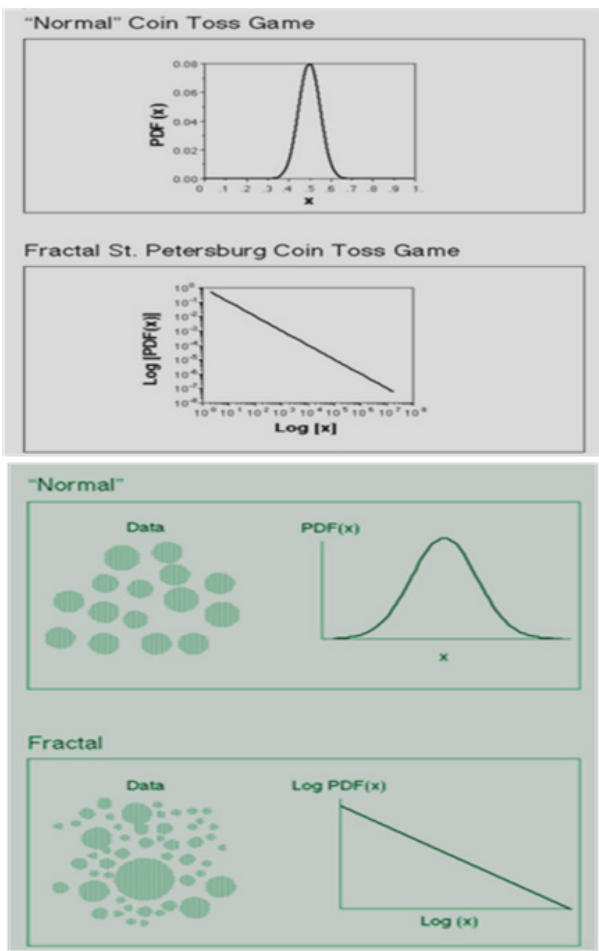

12. ábra. Hatványtörvény eloszlás és normál eloszlás szemléltetése

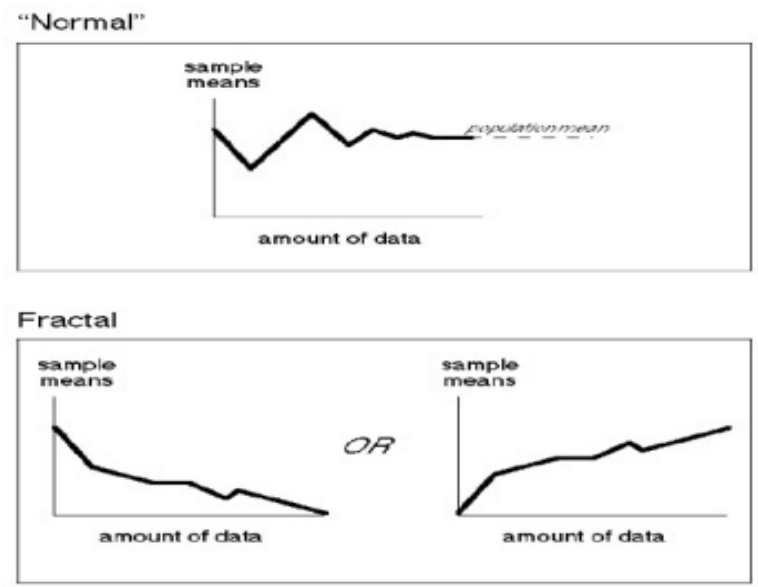

13. ábra. Normál (az átlagérték felé konvergál) és hatványtörvény természete (nem tart egy átlagérték felé) nagyon nagy számú (végtelen felé tartó) megfigyelés esetén 
Kaotikus rendszer és a megfelelő határciklus dinamika viselkedés nagyon közeli kezdeti állapotok esetében. Tehát a határciklus a meghatározó invariáns jellemző és nem a válaszjel időbeni lefutása.

\section{Következtetések}

A számítógépek megjelenésével létrejött információs technológia lehetővé teszi az idegrendszer mint bonyolult hálózat megértését. Neurobiológusok és a fizikai, müszaki tudományok müvelö közös céllal kutatják az idegi információ lényegi kódját, az idegsejtek tüzelési mintázatát [3][4]. A neurális kód legfontosabb összetevője maga az ingerületátvitel, vagyis az idegsejt membránján keresztül lezajló ionkoncentrációváltozás. A sejtek tüzelése egy igen összetett mechanizmuson, a neuronális integráción alapszik, melyben sok száz, sőt adott esetben több ezer bemenetből konvertálódik a végső kimenet, amely ha eléri a kívánt küszöbpotenciált, eredményezhet kisülést (akciós potenciál genezist) a sejtben. Megkíséreljük leírni agyunk müködését, megmagyarázzuk a tudat, a gondolkodás és a memória alapvető eseményét rendszerelméleti szinten. A membránpotenciálok és az esetenkénti akciós potenciálok (AP) vagy más néven spike-ok megfigyelhetőek fiziológiai módszerekkel, intra- vagy extracelluláris elvezetéssel. Az agykérgi neurális hálózati müködés megértésének legfontosabb része a mai legmodernebb technikákkal megvalósuló számítógépes modellezés, vagyis számos idegsejt egyidejü szinkron aktivitásának szimulációja. Ehhez elengedhetetlenül szükséges a neurális rendszerek minden szinten való, minél pontosabb elemzése. Ezt próbálja érzékeltetni az itt bemutatott rövid vázlata az újabb jelelemzési eljárásoknak.

A bemutatott eljárások minőségileg sokat segítenek a biológiai jelenségek pontosabb megértésében, helyes értelmezésében. Mindenik bemutatott eljárásnak elkészült a
MATLAB környezetben használható feldolgozási eljárása és az ezekhez tartozó jelkonverziós módszerek.

\section{Szakirodalmi hivatkozások}

[1] Márton, L. F: Jelek és Rendszerek. [Semnale şi Sisteme] Editura Scientia, 2006. ISBN 973-7953-65-7, 380 old.

[2] Dávid, L., Márton, L.: Rețele neuronale și logica Fuzzy în automatizări. Editura Universităţii „Petru Maior” Târgu-Mureş ISBN 973-8084-02-4 208 old.

[3] Klausberger, T., Magill, P.J., Márton, L.F., Roberts, J.D.B., Cobden, P.M., Buzsaki, G. \& Somogyi, P.: Brain-state and cell type specific firing of hippocampal interneurons in vivo. NATURE, 421 (02/2003). 844-848.

[4] Klausberger, T., Márton, L.F., Baude, A., Roberts, J.D.B., Magill, P.J., and Somogyi, P.: Spike timing of dendrit-targeting bistratified cells during hippocampalnetwork oscillations in vivo. NATURE Neuroscience. 7 (2004). 41-47.

[5] Tél, T., Gruiz, M.: Kaotikus dinamika, Nemzeti Tankönyvkiadó, Budapest, 2002.

[6] Keogh, E., Chotirat A. Ratanamahatana.: Exact Indexing of Dynamic Time Warping. University of California Reviside Computer Science \& Engineering Department CA 92521 USA.

[7] Torrence, C., Compo, G.P.: A Practical Guide to Wavelet Analysis. Program in Atmospheric and Oceanic Sciences, University of Colorado Boulder, Colorado, 1997.

[8] Hardstone, R., Poil, S-S., Schiavone, G., Jansen, R., Nikulin, V.V., Mansvelder, H.D., Linkenkaer-Hansen, K.: Detrended fluctuation analysis: a scale-free view on neuronal oscillations. Frontiers in Physiology Fractal Physiology November 2012. Volume3, Article 450, 6-13.

[9] Berthouzea, L., Farmer, S.F.: Adaptive timevarying detrended fluctuation analysis. Journal of Neuroscience Methods 209 (2012) 178-188.

[10] Chen, Q., Huang, N. E., Riemenschneider, S., and Y.: Introduction to the Hilbert-Huang Transform and its related Mathematical Problems. Adv. Comput. Math. 2005. 
[11] Canolty, R.T., Knight, R.T.: The functional role of cross-frequency coupling. Trends in Cognitive Sciences Vol.14 No.11
[12] Liebovitch, L.S., Scheurle, D.: Two Lessons from Fractals and Chaos. Complexity Vol. 5, No. 4, 2000, 34-43. 